\title{
THE VALUE OF THE ECOLOGICAL STATION OF JATAÍ'S ECOSYSTEM SERVICES AND NATURAL CAPITAL
}

\author{
SANTOS, J. E., ${ }^{1}$ NOGUEIRA, F., ${ }^{2}$ PIRES, J. S. R., ${ }^{1}$ OBARA, A. T. ${ }^{1}$ and \\ PIRES, A. M. Z. C. R. ${ }^{1}$ \\ ${ }^{1}$ PPG-ERN, UFSCar, Via Washington Luiz, km 235, C.P. 676, CEP 13565-905, São Carlos, SP, Brazil \\ ${ }^{2}$ Departamento de Ecologia, UFMT, Av. Fernando Corrêa da Costa s/n, CEP 78060-900, Cuiabá, MT, Brazil \\ Correspondence to: José Eduardo dos Santos, PPG-ERN, UFSCar, Via Washington Luiz, km 235, C.P. 676, \\ CEP 13565-905, São Carlos, SP, Brazil, e-mail: djes@ power.ufscar.br \\ Received November 16, 1999 - Accepted May 18, 2000 - Distributed May 31, 2001
}

(With 5 figures)

\begin{abstract}
The capacity of a given natural ecosystem to provide certain goods and services that satisfy human needs depends on its environmental characteristics (natural processes and components). It was described the availability of these goods and services (environmental functions) controlled and sustained by ecological processes operating in Ecological Station of Jataí (Luiz Antônio, SP). The environmental functions identified were grouped in four main categories. To make environmental values an integrated factor in planning and decision making it was assessed their socio-economic importance in qualitative terms and, if possible their monetary value. The combined potential annual return from identified functions of Ecological Station of Jataí is at least US\$ 708.83/ha/year. In comparison to calculations made for other natural ecosystems this is a rather moderate estimate. The Ecological Station of Jataí is poorly protected and managed, it too is still threatened by human activity (agriculture) and many development plans. Although present day market economics do not recognize the monetary value of most environmental functions, such calculations do provide a revealing insight into the great socio-economic importance of Ecological Station of Jataí. More awareness of these values may provide an important incentive for their preservation and sustainable use.
\end{abstract}

Key words: ecosystem services, environmental functions, natural capital, natural conservation area.

\section{RESUMO}

\section{O valor dos serviços dos ecossistemas e do capital natural da Estação Ecológica de Jataí}

A capacidade de um determinado ecossistema natural proporcionar bens e serviços que satisfaçam as necessidades humanas depende de suas características ambientais (processos e componentes naturais). Foi descrita a disponibilidade desses bens e serviços (funções ambientais), controlados e mantidos pelos processos ecológicos operantes na Estação Ecológica de Jataí (Luiz Antônio, SP). As funções ambientais identificadas foram agrupadas em quatro categorias. Foi determinado o valor sócio-econômico das funções ambientais, em termos quali e quantitativos, quando possível, na perspectiva de integrar os valores ambientais nos processos de planejamento e tomada de decisão. O retorno sócioeconômico anual para as funções ambientais identificadas da Estação Ecológica de Jataí é de aproximadamente US \$ 708,83/ha/ano. Em comparação com estimativas realizadas para outros ecossistemas naturais, esse valor é bastante moderado. A Estação Ecológica de Jataí demonstra ser pouco protegida, com sua manutenção comprometida por atividades humanas (agricultura) e muitos planos de desenvolvimento. Embora o mercado econômico não reconheça o valor monetário da maioria das funções ambientais, essas estimativas não revelam a grandeza da importância sócio-econômica da Estação 
Ecológica de Jataí. Um interesse maior com esses valores pode proporcionar um incentivo importante para sua preservação e uso sustentado.

Palavras-chave: serviços dos ecossistemas, funções ambientais, capital natural, área de conservação natural.

\section{INTRODUCTION}

The need of maintenance of the holistic characteristics and the high degree of interactions among and inside biotic compartments have allowed the formulation of several approaches to ensure environmental quality and ecosystem management (Santos et al., 1995). These approaches incorporate the concept of an operating system, that needs to be manipulated as a whole. However, current day limitations to evaluate socio-economic implications and the effects of human activities in the structure and function of ecosystems (Risser, 1985), determine that benefits of the ecosystems to the society are much more related to their structural aspects than the functional one (Westman, 1977).

The benefits provided by ecosystems are related to the concept of environmental functions, or to the capacity of the ecosystems to provide goods and services that satisfy, directly or indirectly, human needs (Costanza et al., 1997). These functions were grouped in four main categories: Regulation, Carrier, Production and Information Functions (De Groot, 1992). This classification order used is taken from an environmental perspective, in wich case maintenance of essential ecological processes (regulation functions) and suitable living space (carrier functions) provide the preconditions for production and information functions.

The environmental effects of certain human activities or interventions in a given area, cause changes or risks associated on environmental functions, leading to certain socio-economic and cultural effects. These considerations can be applied consecutively in one integrated environmental assessment procedure (Fig. 1), to determine the multiple interactions between human activities and environmental functions. The loss of functions produce irreversible damages to the ecosystems (Ehrlich \& Mooney, 1983), being necessary the application of energy and money to recuperate, mitigate or substitute the affected functions, or the life quality can be threaten.

In spite of the growing knowledge about the importance of natural ecosystems to human welfare, it seems difficult for man to translate this knowledge to into actions to implement the concept of sustainable development (Costanza, 1994; De Groot, 1995). An important obstacle is the development of alternative evaluation techniques, capable to generate information to supply methods of environmental evaluation (Nogueira, 1995; Grasso et al., 1995; Obara et al., 1999).

The market prices are considered the background of economic evaluation techniques of environmental services (Dixon \& Sherman, 1990; Pearce \& Turner, 1990). When the market doesn't exist, the instrument proposed to evaluation refers to the use of the "shadow prices". It is necessary to create a market for them, using the contingent valuation methods (Grasso et al., 1995; Obara et al., 1999).

In order to obtain a clear insight for a complete and systematic analysis of the most relevant functions interrelations between man and a natural ecosystem (Ecological Station of Jataí, Luiz Antônio, SP), to ensure environmental values and constraints an integrated factor in planning and decision-making it was qualified and quantified the socio-economic importance and, if possible the monetary value of the environmental functions provided by Ecological Station of Jataí. The estimated annual return of these functions can provide information in such manner that both public involved and the decision makers are able to understand the great socio-economic importance of the natural area in question and, more awareness about harmful human activities accomplished in theirs surroundings.

\section{Site characterization}

The Ecological Station of Jataí "Conde Joaquim Augusto do Vale" has an area of 4,532.18 ha, and it is located in the municipal district of Luiz Antônio, SP (Fig. 2) among $21^{\circ} 33^{\prime}$ to $21^{\circ} 37^{\prime}$ of south latitude and $47^{\circ} 45^{\prime}$ to $47^{\circ} 57^{\prime}$ of longitude west, with an altitude of 600 m (São Paulo, 1985). 


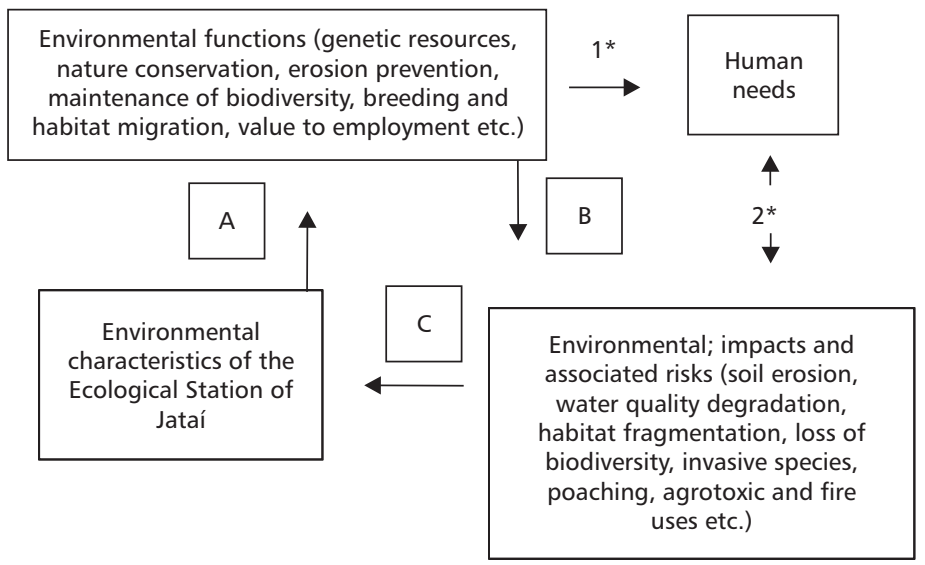

Fig. 1 - Simplified man-environment model applied to environmental functions analysis of Ecological Station of Jataí. A) Analysis of environmental functions (identification of goods and services provided by natural area); B) evaluation of socioeconomic functions (identification and assessment of socio-economic effects resulting from the utilization of goods and services, as well as their economic evaluation); C) environmental impact assessment (analysis of socio-economic and cultural effects caused by changes in environmental functions). * Environmental functions that satisfy direct (1) and indirectly (2) the human needs.

The current day area of Ecological Station of Jataí, locally called Jataí Farm until the end of the 50 's, belonged to an extinct railroad company. The continuous supply of wood for fences, for construction of the railroad and as fuel for machines, caused the decrease of natural vegetation, with the development of current day secondary forest, with a quite different species composition from original community (Toledo Filho, 1984). The wood was also explored for civil construction (houses, school etc.), and for construction of canoes and furniture. The wood species used to attend these proposals were: Aspidospermum peroba, Tabebuia sp., Miroxilum peruiferum, Vernonia sp., Anadenanthera sp. and Xilopia sp. Other species were used as food (Euterpe edulis), and some one as medicinal ends. At that time there were still a pottery factory inside Jataí Farm area, utilising the clay from a natural lake (Sapé Lake), as well as several cultivation areas (rice, corn, potato) and pastures. Hunting either for sport or for food were very common activities accomplished by inhabitants of municipal district area.

In 1959 the Forest Institute of State of São Paulo acquired the area, and changed the name to Experimental Station of Luiz Antônio. Only on the 80 's, it was legally created the Ecological Station of Jataí (Decree of Law 18,997 / June 15, 1982), with the concern of preserving remaining of Cer- rado vegetation and Riparian forest. Ecological Station of Jataí, with an area of 4,532.18 ha, was then separated from the Experimental Station of Luiz Antônio, with an area of 6,240 ha, and it is conserved until the current days.

The physical limits of Ecological Station of Jataí are the Experimental Station of Luiz Antônio at the East border; Boa Sorte Stream and sugar cane monocultive (Capão da Cruz Farm) at the NorthNortheast border; pasture and agricultural cultivation areas (América Farm) at the at the North-Northwest border; Cafundó Stream and private properties with different sizes at the SouthSoutheast border; and the Mogi-Guaçu River at the South-Southwest border (Jesus, 1993).

The climatic conditions are defined by two different periods, a rainy one with higher temperatures and precipitation levels (from November to April) and a dry one, with lower temperatures and precipitation levels (from May to October) (Cavalheiro et al., 1990). The monthly precipitation average during the last 16 years was $128 \mathrm{~mm}$, and during the period between 1972 and 1996 the higher and the lower temperature were 38,1 and $-0,6^{\circ} \mathrm{C}$, respectively.

The relief of area is defined by two great units, the Basaltic Cuestas and the Western Plateau. Most of soils are represented by red-darkness Latossols and deep quartz sands (Pires, 1995). 


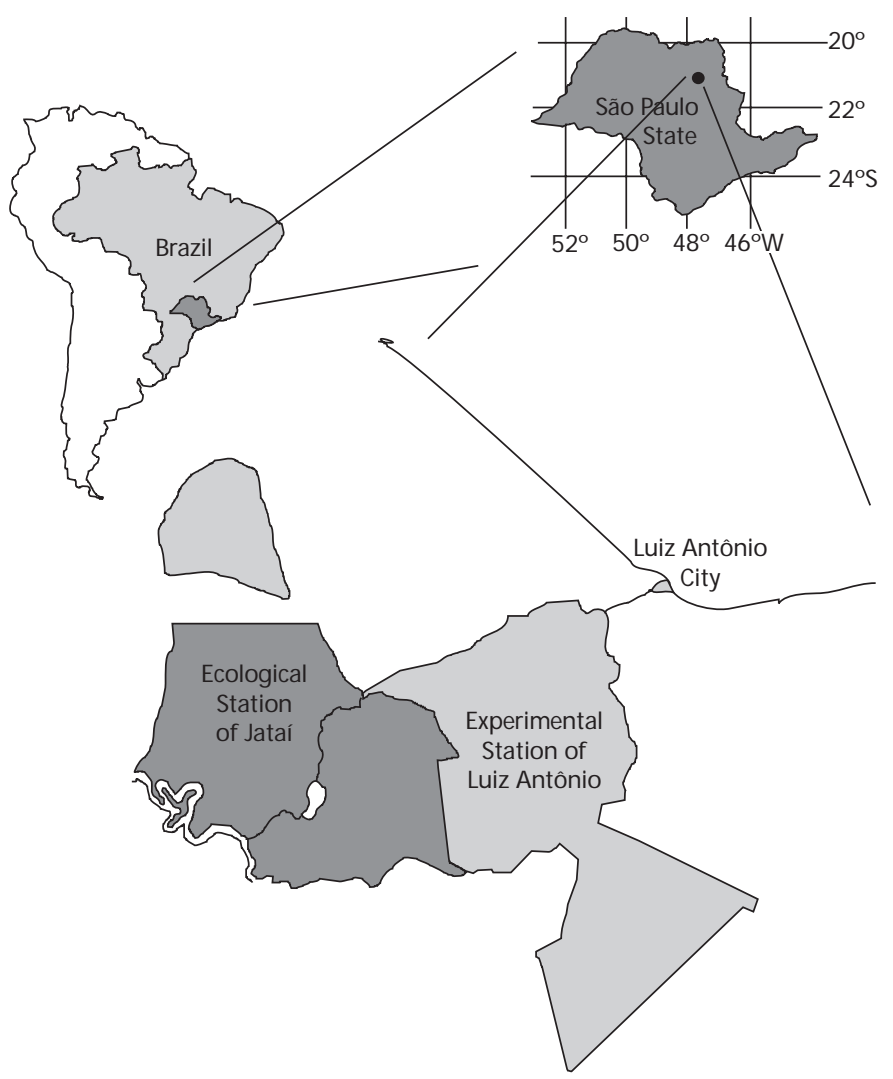

Fig. 2 - Localization of Ecological Station of Jataí.

In Mogi-Guaçu River floodplains hydromorphyc soils prevails, occasionally associated to cambissols (Lorandi et al., 1990).

Ecological Station's category of conservation area is one of the most restricted and also the one that guarantees better protection for biodiversity and integrity of ecosystems included in it. The Experimental Station of Luiz Antônio is an area of public domain, categorized as a Permanent Preservation Area and considered as a Unit of Production (vegetal production). The Experimental Station of Luiz Antônio includes plantations of Pinus and Eucalyptus, that provide wood for industrial and commercial use and resin extraction.

Three basic types of ecosystems are characterized on Ecological Station of Jataí: the aquatic ones, represented by the Mogi-Guaçu River, streams, artificial reservoir and the oxbow lakes; the flooded terrestrial areas and, the terrestrial ecosystems represented by native vegetation and the semideciduous latifoliated forest and, by exotic species plantations, mainly Pinus and Eucalyptus (Ballester et al., 1995).

The Ecological Station of Jataí shows five basic types of soil use (Fig. 3), being native vegetation the most important unit, with about of $83.6 \%$ of total area.

The other uses correspond to reforestation of Pinus and Eucalyptus, agriculture, non identified areas and aquatic ecosystems. Watershed ecosystem analysis applied to Ecological Station of Jataí showed four watersheds (Fig. 3) separate from each other topographically by hillslopes and ridges. The Boa Sorte watershed (BS), occupied by native vegetation, represents the more preserved watershed, while Beija-Flor watershed (BJ), with large proportion area with no conservative uses, shows that $30 \%$ of its surface area needs restoration measures (Pires et al., 1998a). The Main Flooded Area (AP) watershed includes the whole of oxbow-lakes and the main part of floodplain river (Fig. 3). 


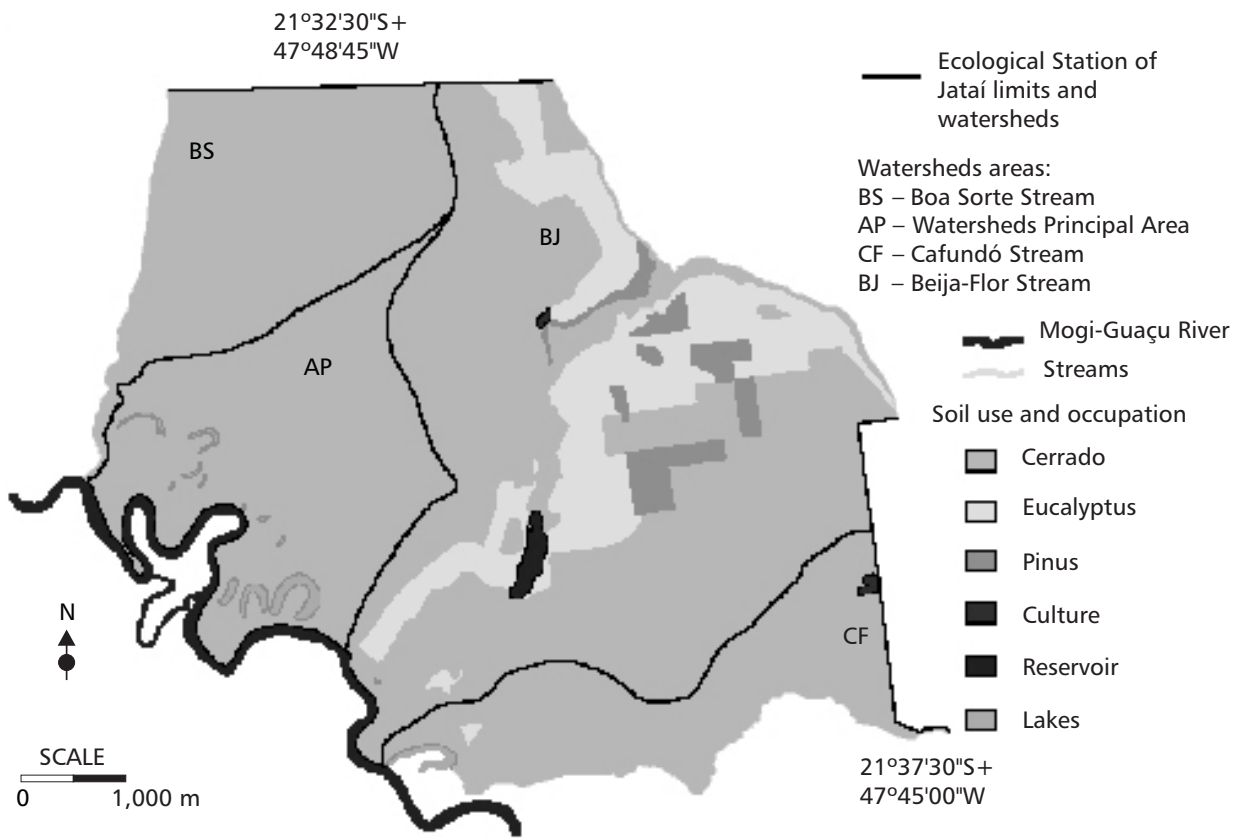

Fig. 3 - Main types of landscape soil use and occupation of the Ecological Station of Jataí.

The surrounding area of Ecological Station of Jataí belongs to the municipal district of Luiz Antônio, and it is occupied by basic production (primary sector) activities like technical agriculture, corresponding to $40,763.30$ ha or $67.93 \%$ of the total municipal district area (Fig. 4). It includes sugarcane cultivation $(44.27 \%)$; reforestation areas $(9.95 \%)$; citrus cultivation $(4.39 \%)$; pasture $(6.93 \%)$ and, other types of use (2.39\%) including cultivation, urban and industrial land use. Natural area totalizing $32.06 \%$ of the remaining area, includes the Riparian forest, flooded area, aquatic ecosystems, hill side and hill top vegetation and mainly the Cerrado vegetation (19.83\%), including Ecological Station of Jataí (Pires et al., 1998b). Secondary sector is represented by two industries: Votorantin Cellulose and Paper (Celpav) and alcohol and sugar plants. Other agro-industries influence the landscape soil use in the municipal district, especially the alcohol and sugar plants located in neighbouring municipal districts. The tertiary sector is quite inexpressive, with poor commercial facilities and essential health services.

Several environmental impacts (stream degradation; soil erosion; riparian forest degradation; agrotoxic and fire use; invasive species; poaching; habitat fragmentation and, loss of biodiversity) resulting from agricultural, industrial and urban landscape soil use (Pires \& Santos, 1996) are threatens the environmental quality and conservation of Ecological Station of Jataí (Fig. 5). There are also the effects of organic and industrial loads (paper industry, urban wastes, sugar and alcohol plants, sand mining etc.) from about 39 municipal districts in Mogi-Guaçu River watershed (Cetesb, 1991). Sand mining activity can affect also water quality and fluvial geomorphology of Mogi-Guaçu River floodplain (Pinto, 1992).

At the Experimental Station live about 40 people, between the employees and their families. They work in the wood cultivation (Pinus and Eucalyptus) and on fiscalization of Ecological Station of Jataí. Beehives are installed for honey production when Eucalyptus are flowering, and a percentile of the profits is given to administration of Ecological Station of Jataí. The resin from the pine trees is also explored, and a percentile at about $30 \%$ of the profits also stays with the administration. In the honey and resin exploration there are about 12 employees. 


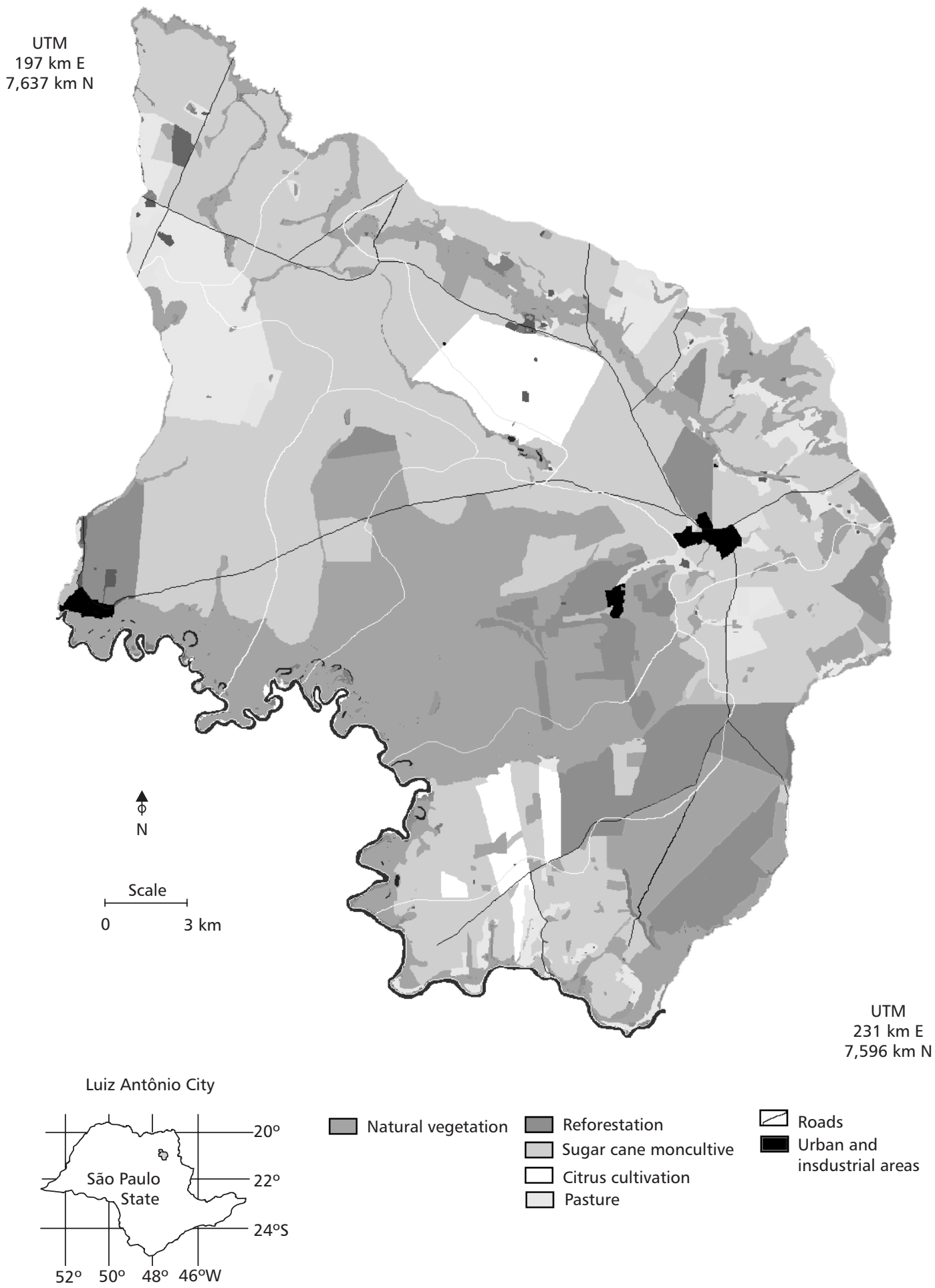

Fig. 4 - Thematic maps with main types of soil use obtained from LANDSAT TM 5 image of the study area. 


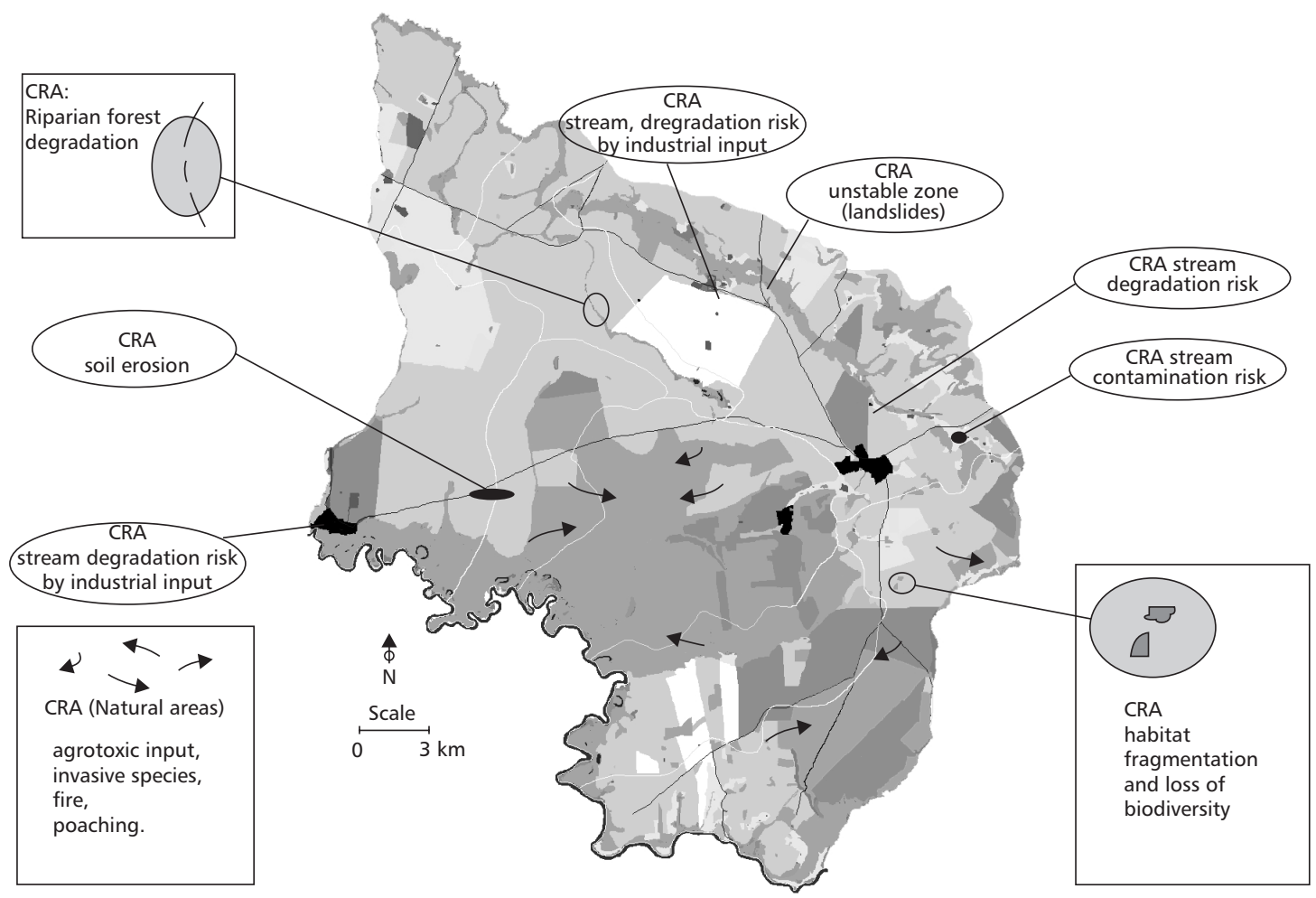

Fig. 5 - Map of the Critical Risk Areas (CRA) with respectives environmental risks and impacts observed in the study area.

\section{MATERIAL AND METHOD}

\section{Socio-economic evaluation of environmental functions}

The assessing of environmental functions of Ecological Station of Jataí must be realized by the fact that most environmental characteristics influence more than one function. Each function was considered the result of the interactions between dynamic and evolving process and components of the ecological sub-systems included in the natural conservation area. The availability of environmental functions depends on the maintenance of the integrity of the entire natural area wich provide them.

When assessed sustainable use levels of Ecological Station of Jataí environmental functions it was considered a distinction between biotic versus abiotic and renewable versus non-renewable functions. Environmental functions that cannot be used in a sustainable manner (e.g. the conversion of Ecological Station of Jataí for permanent human construction) are left out of this research. Another important restriction in evaluation the functions of Ecological Station of Jataí is the fact that some regulation functions are of such a scale and nature that is practically impossible to quantify the contribution of Ecological Station of Jataí to such a function. However, the cumulative contribution of sub-systems included on the Ecological Station of Jataí is essential for the maintenance of the regulation functions. The loss of biodiversity or the climatic regulation conditions are the result of the cumulative effect of many small-scale land use decisions observed in the Luiz Antônio landscape municipal district (Fig. 4).

It was made a general description of functions that can be attributed to Ecological Station of Jataí. For each function, a brief introduction of the ecological importance was given. When functions that cannot be used in a sustainable manner, and/or for wich quantification is difficult, it seemed useful to include some information on socio-economic qualitative value. 


\section{RESULTS AND DISCUSSION}

\section{Regulation Functions}

Climatic regulation: The landscape diversity related to different types of ecosystems (Pires et al., 1998a) included on Ecological Station of Jataí (Fig. 3) and the many land uses intervention (Pires et al., 1998b) on the surrounding area (Fig. 4), has a differential effect on micro-climatic conditions, influencing hydrological conditions (evaporation and rainfall), radiation balance and temperature fluctuations. There are evidences of climatic deterioration in local scale caused by deforestation and agricultural activities in surrounding of natural conservation area. Dry streams were also verified, as a consequence of Riparian vegetated strips converted to sugar cane mono culture (Pires \& Santos, 1996). The deforestation causes changes in albedo, wich rises $10 \%-16 \%$ when tropical moist forest are converted to arable land (De Groot, 1992). Changes in albedo thus influences the heat balance in the deforested area, wich not only changes local climatic conditions but wich also has possible consequences for the regional climate. Mainly, when the deforested area is substantially large as observed in Luiz Antônio municipal district (Fig. 4) with around $67 \%$ of municipal district total area occupied by agricultural activities, reforestation and pasture (Pires et al., 1998b).

Watershed protection and soil erosion prevention: The natural vegetation covering four watershed of Ecological Station of Jataí (Fig. 3) regulates the quality and quantity of water leaving those areas, providing also a control effect on extreme water levels further downhill in the catchment area of Mogi-Guaçu River. This vegetation reduces floods during the rainy season and prevents water shortage during the dry season. Natural vegetation, especially on Mogi-Guaçu River and tributaries, also reduces runoff allowing more water to infiltrate into the soil thus feeding underground water reservoir, river and lakes. Riparian vegetated buffer strips can modify, incorporate, dilute or concentrate substances and sediment input before they enter in oxbow lakes (Albuquerque \& Mozeto, 1997), influencing the structure of aquatic community and affecting functional process in the Mogi-Guaçu River (Simões-Filho, 1993). Water catchment and erosion prevention by the natural vegetation is a function with considerable socio-economic importance to prevent damage to the pollution and destruction of freshwater biota, and the reduction of the life span of waterways.

Thibodeau \& Ostro (1981) calculated in US\$ $5,000.00 /$ ha/year the shadow price for the flood prevention function provided for the flooded areas, representing the damage that would happen if the area went dry.

As an indication of the monetary value involved for the flood prevention at the Ecological Station of Jataí it was considered as a minimum estimate a figure of US\$ 500.00/ha/year, being $10 \%$ of the value calculated by Thibodeau \& Ostro (op. cit.) (Table 1).

Intensive permanent cultivation of sugar cane and citrus (Pires \& Santos, 1996; Pires et al., 1998b) with larger inputs of fertilizer and pesticides in the surrounding area of Ecological Station of Jataí, associated with the removal of natural vegetation had been increased the soil erosion process and the loss of habitat resulting from fragmentation of the original landscape occupation (Fig. 5).

In case of a hypothetical agricultural use (sugar cane monoculture) of terrestrial area $(3,150$ ha) of Ecological Station of Jataí, soil erosion caused by runoff carries 928,570 t/year of soil into MogiGuaçu River, tributaries and oxbow lakes. These effects leading to extra costs of US\$220,000.00 for dredging operations (Margarido \& Santos, 1996). It means that the potential socio-economic value of prevention of soil erosion and sediment control by maintaining natural vegetation in Ecological Station of Jataí is US\$ 69.84/ha/year. In spite of estimate procedure represent only a hypothetical situation, it is possible to show that economic costs are quite elevated to mitigate just one of externalities that come from agricultural activities.

Considering that just $10 \%$ of the Mogi-Guaçu River discharge is demanded by domestic drinkwater of Luiz Antônio city, and that soil erosion determines an increase in turbid conditions of water (at least in 10 units), the increment in economic costs for treating water quality in relation to annual aluminium sulphate used, will be about of US\$ 41,000.00 (Margarido \& Santos, op. cit.), meaning a socio-economic value of US\$ 13.01/ha/year. 
TABLE 1

Socio-economic values of the environmental functions of the Ecological Station of Jataí (based on maximum sustainable use levels). Values are expressed qualitatively $(++)$ or in US\$/ha/year. Total surface area of the Ecological Station of Jataí: 4,532.18 ha.

\begin{tabular}{|c|c|c|c|c|c|c|}
\hline \multirow[b]{2}{*}{ Environmental functions } & \multicolumn{6}{|c|}{ Types of values } \\
\hline & $\begin{array}{c}\text { Conservation } \\
\text { value }\end{array}$ & $\begin{array}{l}\text { Existence } \\
\text { value }\end{array}$ & $\begin{array}{c}\text { Social } \\
\text { values }^{(1)}\end{array}$ & $\begin{array}{l}\text { Consumptive } \\
\text { use value }\end{array}$ & $\begin{array}{c}\text { Productive } \\
\text { use value }\end{array}$ & $\begin{array}{c}\text { Value to } \\
\text { employment }\end{array}$ \\
\hline Regulation functions & $>617.88$ & ++ & ++ & & & \\
\hline 1. Climatic regulation & ++ & & + & & $*$ & \\
\hline 2. Flood prevention & 500.00 & & + & & $*$ & \\
\hline 3. Soil erosion prevention & $83.23^{(2)}$ & & & & $*$ & \\
\hline 4. Bioenergetic fixation & ++ & + & & & $*$ & \\
\hline \multicolumn{7}{|l|}{ 5. Storage and recycling of: } \\
\hline organic matter, & ++ & & + & & $*$ & \\
\hline nutrients and & $13.65^{(2)}$ & & + & & $*$ & \\
\hline industrial \& domestic wastes & ++ & & + & & & \\
\hline 6. Biological control & $5.70^{(3)}$ & ++ & ++ & & $*$ & \\
\hline $\begin{array}{l}\text { 7. Maintenance of migration } \\
\text { and nursery habitats }\end{array}$ & ++ & ++ & ++ & & $*$ & \\
\hline 8. Maintenance of biodiversity & ++ & ++ & ++ & & $*$ & \\
\hline Carrier functions & 3.70 & 3.00 & 2.00 & & 2.10 & $>9.56$ \\
\hline 9. Recreation & & & & & 2.10 & + \\
\hline 10. Nature protection & 3.70 & 3.00 & 2.00 & & $*$ & 9.56 \\
\hline Production functions & & & + & + & ++ & + \\
\hline 11. Genetic resources & & & + & & + & + \\
\hline 12. Medicinal resources & & & + & + & ++ & + \\
\hline $\begin{array}{l}\text { 13. Raw material for } \\
\text { construction and handmade } \\
\text { works }\end{array}$ & & & & & + & + \\
\hline Information functions & & & ++ & ++ & $>21.46$ & 64.40 \\
\hline 14. Aesthetic and historic & & & ++ & ++ & + & \\
\hline 15. Scientific and educational & & & & + & 21.46 & 64.40 \\
\hline $\begin{array}{c}\text { TOTAL ANNUAL VALUE } \\
(>>708.83)\end{array}$ & > 606.31 & $>\mathbf{3 . 0 0}$ & $>2.00$ & ++ & $>\mathbf{2 3 . 5 6}$ & $>>73,96$ \\
\hline
\end{tabular}

(*) These functions contribute to economic productivity, either directly or indirectly, but no market or shadow price could be determined due to lack of information.

(1) Social values: Importance of environmental functions to human health and the option value placed on a safe future.

${ }^{(2)}$ This function applies to the terrestrial area only (3,150 ha).

(3) This function applies to 6,998 ha of sugar cane culture $(44,27 \%$ of the total municipal district area). 
The hypothetical agricultural use of Ecological Station of Jataí demonstrates that annually would be lost through soil erosion process an amount of nutrients equivalent to US\$ 1,300.00 (Margarido \& Santos, op. cit.), or US\$ 0.41/ha/year. The costs of prevention of soil nutrient loss by soil erosion was not expressive, due to the low concentrations in the soils of natural conservation area.

The total economic costs of US\$262,300.00, equivalent to US\$ 83.26/ha/year (Table 1), represents the potential socio-economic value for soil erosion prevention provided naturally by Ecological Station of Jataí. This total value encompasses the annual cost of dredging, the treatment of water quality and the loss of soil nutrients. Represents a convincing economic argument to maintenance of natural conservation area.

Bioenergetic fixation: The total amount of solar energy wich can be fixed by an ecosystem in a given time period is the basis of almost all other functions performed by natural ecosystems. This function may be considered as the life support value of a natural ecosystem (Gosselink et al., 1974). About $80 \%$ of total area of Ecological Station of Jataí is covered by natural forest (Fig. 3), absorbing and transforming great amount of solar radiation through photosynthesis into biomass vegetation. By using this overall life support value is possible to give an indication of the potential value of other regulation functions combined without having to specify how the available energy is divided into different uses and functions. Until now, however there is no information available about production capacity (biomass production) of Ecological Station of Jataí. This method, however is rather controversial, and is not included in the sum total of monetary values wich are calculated for separated functions.

Storage and recycling of organic matter, nutrients and industrial and domestic wastes: Ecological Station of Jataí contributes in various ways to the storage and recycling of the organic matter produced in aquatic, flooded and terrestrial systems included on local area. In general, aquatic and flooded areas on Ecological Station of Jataí are better able to decompose large amounts of organic matter with respect to flood pulse, and without evidences of eutrophication process. Some idea of intense metabolic activity that accompanies organic matter degraded is obtained by observation of the increase temperature in the substrate and water column of oxbow lakes (Ballester, 1994; Camargo \& Esteves, 1995; Nogueira et al., 1996; Albuquerque \& Mozeto, 1997), and also the high populations of micro-organisms (Freitas, 1989).

The production and decomposition of different litter fractions of riparian forest, as well as the quantification of chemical elements have demonstrated nutrients storage and liberation capacity from forest biomass to the soil compartment, oxbow lakes and floodplain on natural area. The litter production is relatively high (12 tonnes/ha/year), when compared to the production of temperate and tropical forests. The litter needs around one year $\left(\mathrm{t}_{50 \%}\right)$ to decompose. Likewise the time for upland forests from the São Paulo State. Decomposition speed associated to flood pulse favours accumulation of high amount of organic matter in the surface soil (Pinto, 1992).

The most important contribution of flooded areas is the removal and recycling of inorganic nutrients (e.g. nitrogen and phosphate) during rainy season when the waters of the Mogi-Guaçu River overflowed to the wetland. When nutrient rich water enter on flooded area, nitrogen and phosphate are effectively trapped and assimilated in the productive biological systems (e.g. aquatic macrophytes and phytoplankton of oxbow lakes and riparian vegetated strips) (Nogueira et al., 1996; Albuquerque \& Mozeto, 1997).

The role of the oxbow lakes as sinks or as sources of nutrients is an open question. The study of an oxbow lake related to the Mogi-Guaçu River (Camargo \& Esteves, 1995), showed that the system works as a source of nitrogen and as a phosphorus sink. However, this oxbow lake stands out of the Ecological Station of Jataí limits, in a degraded landscape resulting from different types of land use, such as intense deforestation, pasture and agricultural activities. However, nitrogen and phosphorus dynamic cycles in Infernão Lake, inside the Ecological Station of Jataí, evidenced an increase of nutrient concentration during rainy season (Nogueira et al., 1996). It seems that oxbow lake works as a sink compartment, since nutrients were quickly assimilated by the producers. The fixation of nitrogen by terrestrial ecosystem $(3,150 \mathrm{ha})$ on 
Ecological Station of Jataí was utilised as a parameter of the (economic) importance of natural recycling mechanism. According fertiliser's market price biological nitrogen fixation represent an annual value of about US\$ 43,000.00 (Margarido, 1995) or US\$13.65/ha/year (Table 1). Biological nitrogen fixation was underestimated because diazotrophic bacteria activity that occur associated to arboreal legumes was not considered. Studies accomplished in Anadenanthera sp. have been evidencing the importance of these arboreal species in terms of nitrogen supplying for similar cerrado vegetation areas (Carmo, 1994).

To a limited extent, Ecological Station of Jataí is able yet to maintain a healthy environment by storing and recycling certain amounts of organic and inorganic human waste. However, due to man's landscape use as a free dumpsite, is becoming clearly visible many environmental problems on Ecological Station of Jataí's surrounding (Fig. 5), such as soil erosion, lakes and streams water quality degradation, habitat fragmentation, and problems related to pollution (e.g. pesticides, heavy metal and agrochemical) (Pires \& Santos, 1996), with recycling mechanisms seriously threatened.

Heavy metals concentration in sediments of oxbow lakes demonstrate no contamination level, with lower values than those found in dams and fluvial systems moderately polluted. However, concentrations of chromium in E. azurea and in two fish species ( $S$. nasutus and H. malabaricum) suggest that this metal should be better investigated (Lima, 1990).

Chlorine pesticide in water column of oxbow lakes show value around $0.001 \mathrm{ppm}$, above the level admitted by EPA (Environmental Protection Agency) for preservation of aquatic organisms (Obara, 1992). This value is resulting from effects of agricultural activities in water quality of aquatic ecosystem of the Ecological Station of Jataí.

High level of faecal coliforme found in Diogo Lake is resulting from influence of its tributary Cafundó Stream, that has their headwater in soil occupied by agricultural activity (Barroso, 1994).

Biological control: Species in natural ecosystems have developed complex interspecific interactions (food chains, predator-prey and parasite-host relationship etc.), as a result of the evolutionary process. Many of these interactions are not only important in maintenance the biological balance within ecosystems. They can also provide benefit to man, especially for pest control and pollination of crops. Natural ecosystem control more than $95 \%$ of all potential pests of crops and carriers of disease to human beings (Ehrlich, 1985). At the same time it must be noted that natural ecosystems also are the sources of these harmful species whereby man usually is the trigger that turns these species into pests by upsetting the natural balance (De Groot, 1992).

By maintaining the Ecological Station of Jataí in agricultural area of Luiz Antônio municipal district (Fig. 4) a certain biological balance can be maintained wich helps reduce damage caused by pests of crops. Natural ecosystems included on Ecological Station of Jataí bordered by sugar-cane culture, can have a regulating influence on the outbreak of pests in this neighbouring crop since they provide shelter to predators wich feed on Diatraea saccharalis wich is potencially harmful to the sugar-cane cultive. A decrease around 0,8\% in intensity occurrence of Diatraea saccharalis in sugar-cane culture (Margarido \& Castilho, 1988), can determine a monetary gain increase, of about US\$ 5.70/ha/year (Table 1), for 6,998 ha of sugarcane productivity on Ecological Station of Jataí's surrounding cultivation area. An apparent conflict of socio-economic value carried out by biological pest control function refers to environmental perception developed by the surrounding landowners of Ecological Station of Jataí, that consider this natural area the source of pests species of crop (Santos et al., 1996).

\section{Maintenance of migration and nursery habitats:} Most animals, both resident and migratory use different habitats on Ecological Station of Jataí within their home-range for breeding, feeding and resting. Because of the border-position between natural and cultural areas, cerrado vegetation provides temporary habitats to many species (Talamoni et al., 1994). Some conspicuous animal movements are those of birds and mammals, since Ecological Station of Jataí provides food and shelter to those animals wich spend only part of their life cycle in this natural area. The actual number of birds depending on this natural area is still much higher because there is a continuous flow of birds through Ecological Station of Jataí. However, disturbance 
and destruction on Ecological Station of Jataí surroundings will have serious consequences for these species and thereby for the functioning of other ecosystems. In view of the fragmentation of the landscape caused by human activities, like cultivation, road construction etc. (Pires \& Santos, 1996), some attention must be given to corridor function of Ecological Station of Jataí and surrounding area (Fig. 4). Certain natural fragments and riparian forests can be considered as corridors wich enable animals to move from one habitat to the next. Mogi-Guaçu River wetland with a expressive net biomass production (Nogueira et al., 1996; Coutinho, 1989) is especially important as feeding and resting habitats (Talamoni, 1996). In general, it can be considered that higher the net-production biomass, the more migratory species can be supported by a given ecosystem (De Groot, 1992).

The importance of Ecological Station of Jataí as nursery area is evidenced to the dependence of the fish communities of oxbow lakes on the MogiGuaçu River wetland as a place for breeding and reproduction (Esteves, 1992; Meschiatti, 1998). However, the value of Ecological Station of Jataí as nursery in terms the number of breeding fish species of wich over $1 \%$ of a local population, is still unknown. The lack of data about fish biomass impedes any evaluation regarding socio-economic value of this function, in terms of a possible commercial exploration. The destruction of the flooded areas by agricultural practices (agrotoxic contamination) can reduce the socio-economic value of this function. These socio-economic benefits would only be considered if Ecological Station of Jataí could admit tourism activity.

Maintenance of biological diversity: Protective representative sample of aquatic, flooded and terrestrial ecosystems within Ecological Station of Jataí are essential for maintenance biological (and genetic) diversity restricted to this geographical zone. The importance of this natural area for the maintenance of this function may be deduced from species diversity, presence of endemic and rare/endangered species, and their naturalness. We still have to identify most of the species, and their properties, wich are living in the Ecological Station of Jataí, and to make sure their continued survival for man's different purposes. To the knowledge of the researchers, no endemic species or subspecies are known in the natural area in question. However, as a result of human activities on surrounding of Ecological Station of Jataí, both habitat fragmentation (Fig. 4) and killing of wild animals, many species have become rare or endangered. To the aquatic environments (oxbow lakes) phytoplankton richness is highly varied, although just some species are quantitatively important (Dias, 1991). To the periphyton material 181 algae species were identified, some of them coming from phytoplankton community (Schwarzbold, 1992). In spite of importance terrestrial ecosystems as refuge area for several animal species (some of them vulnerable or even threatened), only a few systematic research were accomplished involving guará wolf (Chrysocyon brachyurus), the largest representative of the Canidae in South America (Talamoni, 1996; Mantovani, in prep.). These studies indicate a decrease of all functional areas (e.g. breeding, feeding and resting habitats) of the specie involved as a resulting from fragmentation of the landscape caused by human activities. Besides the guará wolf, Felis concolor, Tayassu tajacu, Callicebus lanatus, Myrmecophaga tridactyla, Nasua nasua and Caluromys anatus were also observed in natural area (Talamoni \& Motta Jr., 1994).

No monetary value was estimated for this function, but the biodiversity in Ecological Station of Jataí represents a considerable conservation (as well as of option and existence) value.

\section{Carrier functions}

Selective forestry/agriculture/aquaculture/recreation: The use of carrier functions by human land use involves a significant alteration of the natural environmental conditions. Sustainable use of carrier functions necessarily implies great limitations to the type and scope of human activities. Agricultural, aquacultural, recreational and forestry activities that can be developed in natural areas in a sustainable manner, since they are well-managed and integrated in conservation strategies, are not allowed inside Ecological Station of Jataí. Because of the constraints with respect to the sustainable use of carrier functions only the nature protection wich depend on the natural biological characteristics of the Ecological Station of Jataí, and wich can be utilised without serious damage to the conservation value are included here. However, current soil use on Ecological Station of Jataí evidences remains 
of forestry activities, represented by Pinus and Eucalyptus mono cultures (Fig. 3), referring to the period that this natural area belonged to the Experimental Station of Luiz Antônio. With lawful creation of the Ecological Station of Jataí in 1982, forestry activities were interrupted because of the constraints related to the basic objectives established for this natural area category (Table 1). Since that period natural replacement of forestry areas by secondary forest is occurring.

The use of Ecological Station of Jataí surroundings for intensive cultivation of sugar cane mono-cultures has negative effects on landscape area (Pires \& Santos, 1996), influencing surrounding land-owners attitude with respect to the natural area. This socio-cultural group realize that Ecological Station of Jataí is large enough just for conservation purpose, and has to be used also for crop growing (Santos et al., 1996). This attitude is likewise for decision-makers socio-cultural group (Silva, 1997).

Aquaculture deserves to be highlighted as management possibility because of aquatic ecosystems in the Ecological Station, although just about $2 \%$ of total natural area are permanent or periodically flooded (Pires, 1994). Considering the relatively stable water temperatures of oxbow-lakes on natural area (Barroso, 1994), it should be possible to exploit fish productivity (Esteves, 1992; Meschiatti, 1998) on a sustainable basis without interfering with conservation interests.

The suitability of Ecological Station of Jataí for recreation is related to the quality of their scenery and the presence of animal wildlife (Obara, 1999). Recreational (sport fishing or hunting) activity on Ecological Station of Jataí is experienced by many people, although not allowed. About 150 people/day during a weekend practise sport fishing in oxbow lakes, streams or in the reservoir included on natural area. The entrance fee is free of tax but identity document are retained during stay period of time in natural area. According manager administration of Ecological Station of Jataí local sport fishing is manual but fishing net are still apprehended with fishermen.

Nature protection: The total area designated for nature protection in the Ecological Station of Jataí is $4,532.18$ ha. Two important criteria that determine the conservation value are naturalness and uniqueness. It is still relatively undisturbed and a very dynamic natural area with special riparian zone and oxbow lakes of Mogi-Guaçu River floodplain and a remainder cerrado vegetation that have a great cultural and scientific value (Decree of Law n. $18,997,15 / 06 / 82$, SP). Other relevant features in relation to the conservation value are species richness and diversity, and also a very valuable feeding and resting area for many species of birds, migrants as well as breeding species (Talamoni \& Motta Jr., 1994).

The total area designated to nature protection has been questioned as insufficient in terms of their capacity to play a role in biological conservation. It is necessary a change on the management objectives and the increase of Ecological Station of Jataí physical area including Experimental Station of Luiz Antônio, with a proposal of the Jataí State Park with about 11,000 ha (Pires, 1999). This new category of natural area will allow certain types of use that do not interfere with the Ecological Station of Jataí conservation objectives. This proposition finds back up in the concern of State Environmental Control Agency in disabling human activities inside the Experimental Station incorporating this area together Ecological Station of Jataí's area.

The economic benefits of maintenance of Ecological Station of Jataí were estimated by the Contingent Valuation Method (Obara et al., 1999). The methodology involved the establishment of a hypothetical market, in that the individuals are questioned about their preferences by certain goods or services that doesn't present a real market value. They were asked about their Willing to Pay (WTP) for compensation regarding the maintenance and conservation of Ecological Station of Jataí. The annual total WTP estimated to inhabitants of the Luiz Antônio municipal district related to Ecological Station of Jataí was US\$ 49,034.05 as a result of sum of the use value (recreation value) estimated in US\$ 9,547.05 (or US\$2.10/ha/year) and the non use values (inheritance value + existence value + option value), respectively estimated in US\$ $16,755.15,13,798.38$ and $8,933.47$ or respectively US\$ 3.70, 3.00 and 2.00/ha/year (Table 1). The inheritance value (the guarantee that the future generations can know Ecological Station of Jataí) and the existence value (the guarantee existence of plants and animals in the Ecological Station of Jataí) were main motivations to preservation of natural area related to the total of money allocated 
by population. As a comparison, to a littoral area at the South of São Paulo State, Brazil, it was estimated an average WTP value about US\$ 43.85/ month to preserve growth of mangroves located in the area, submitted to indiscriminate destruction by local tourism (Grasso et al., 1995).

The Ecological Station of Jataí also provides employment, safeguard opportunities for other uses (such as research), and provide many other benefits such as regulation and information functions. No information was obtained on the actual amount of money involved in the conservation management of natural area. But Table 1 shows that only five people find employment in managing activities (maintenance of infrastructure, personnel etc.) wich are directly related to nature protection. The socioeconomic importance of this function related to management costs involved employees' salary, corresponds on annual average US\$ 43,368.00, or US\$ 9.56/ha/year (Table 1).

\section{Production functions}

Genetic resources: Although the wildlife in Ecological Station of Jataí represents a reservoir of genetic material, thus far little research has been undertaken to study its potential for use. To maintain the evolution of wild genetic material, the conservation of species in this natural area is essential. Parameters for assessing the importance of wild species (Chrysocyon brachyurus) for this function involving their genetic properties and population viability are been studied.

Medicinal resources: Although today most of the medicinal products are taken from cultivated plant and animal species, natural protected areas are still essential because they safeguard the wild stock of genetic information. The use of wild plant species for medicinal purposes is significant at the rural environments or in some traditional cultures. Information about plants with medicinal properties are obtained with local inhabitants from Experimental Station of Luiz Antônio. This survey revealed a total of 134 species distributed in 51 families, and indicated for 81 therapeutic uses (Castelucci, 1995). The occurrence of these plants is related to Ecological Station of Jataí and Experimental Station of Luiz Antônio areas.
Raw material for construction and handmade works: In spite of they are not explored two types of natural materials used on civil construction and on handmade work were identified in the Ecological Station of Jataí. In the first case, are sandstone and basaltic rock, frequently used in urbanisation projects, in second case occurs a kind of clay extracted from Sapé Lagoon and from Beija-Flor Stream (Fig. 3) that can be used for artisan works. This clay extraction process occurred since the beginning of the 60's. However, it was interrupted by interference of Luiz Antônio Experimental Station' administration because negative effects caused in freshwater (reservoir, lake and stream) ecosystems. To avoid possibility for clay extraction Beija-Flor Stream was dammed with drastic change of local landscape. The artificial dam developed on landscape (Fig. 3) became another place for sport fishing activity, and also became an additional breeding habitat for many species of fishes.

The selective forestry of Pinus and Eucalyptus for wood and resin extraction. are not accomplished inside Ecological Station of Jataí in current day and it is also disabled at the Experimental Station of Luiz Antônio. It has been emphasized management decisions involving forestry mono-cultures replacement by natural vegetation through secondary succession process.

\section{Information functions}

Providing aesthetic and historic information: Natural environments provide a inspirational and educative forme of re-creative experience, with opportunities for reflection, spiritual enrichment and cognitive development through exposure to life process and natural systems. Although methods to analyse the aesthetic value of scenic landscape exist (Obara, 1999), the appreciation of the scenery is a highly personal experience. The Ecological Station of Jataí scenery seems to evoke contrasting feelings and attitudes with spectators (fishermen, researchers, surrounding land-owners, decisionmakers, primary school teachers, employees and manager of the natural area) ranging from dejection to excitement and wonder (Santos et al., 1996). Most people from Luiz Antônio city seem to feel most confortable in a natural landscape bordered by medium-dense vegetation (Obara, 1999). 
There are certain structural or specific landmarks on Ecological Station of Jataí, such as Diogo lake, the remains of Jataí's Harbour and Mogiana railroad, to wich people from Luiz Antônio city attach emotional or heritage values. The destruction of these landmarks is experienced as a personal or collective loss (Maroti \& Santos, 1998). The historic value of these areas or elements should therefore be accounted for in the planning and decisionmaking process.

Providing scientific and educational information: The Jataí Ecological Station provides many opportunities for nature study, environmental education, and basic and applied scientific research. Some general parameters for assessing the suitability of Ecological Station of Jataí for education and scientific research include biotic and abiotic diversity, fragmentation of habitats, species and abiotic features occurring in the natural area, and the presence of indicator species or processes. The potential value for research and education of Ecological Station of Jataí is also influenced by the accessibility and vicinity to research institute (e.g. Federal University of São Carlos) and urban areas. Over twelve years (1987-1999), at least 70 researchers carried out field research in natural area. Literature compilations on research done in the Ecological Station of Jataí number thousands of titles stored on library of the Federal University of São Carlos.

The economic value of this function was estimated by a calculation of the number of scientific expeditions organise in Ecological Station of Jataí, during 1987-1999, and the amount of money involved in these activities. The estimate of researchers and technicians salaries; scholarships in level of Master and Doctorate granted to projects; expenses with scientific expeditions in terms of daily and fuel, and equipment and consumption material, would amount to a total of US\$291,880.00/year, or US\$ 64.40/ha/year (Table 1).

Considering an educational value of $1 / 3$ of the research value (De Groot, 1992), the total cognitive value of the Ecological Station of Jataí would be about US\$ 21.46/ha/year (Table 1).

\section{Total socio-economic value of the Ecological Station of Jataí}

The Ecological Station of Jataí fulfils many functions wich, directly or indirectly, contribute to human welfare. The various types of socioeconomic values that can be attributed to the functions of this natural area and, their monetary value is summarized in Table 1. It is important to realize that the data presented in Table 1, are very crude estimations and probably underestimate the true socio-economic value of the natural ecosystem in question. They represent a first attempt of the evaluation of the goods and services provided by Ecological Station of Jataí, as well as a subsidy for further research to support more detailed and accurate data.

The conservation value mainly consists of the benefits derived from leaving Ecological Station of Jataí in its natural state. As these functions operate better in absence of disturbances, this type of value is referred to as "non-use value" and mainly relates to regulation and carrier functions that have direct importance to the human welfare. The functions wich together determine the conservation or non-use value of Ecological Station of Jataí (Table 1) are used as important arguments for conserving this area. As a undisturbed area Ecological Station of Jataí regulates certain environmental conditions that are essential to the maintenance of a healthy living environment. For some regulation functions (flood and soil erosion prevention, storage and recycling of nutrients and biological control) and one of carrier function (nature protection) a monetary value was estimated through shadow prices, with a final value of US\$ 603.31/ha/year (Table 1). Indeed, this conservation value of environmental functions may far outweigh the direct consumptive and productive use values of the natural area in question. However, to measure the socio-economic benefits of the non-use values of Ecological Station of Jataí is very difficult and depends on the type of function and on the scale on wich it is operating. To quantify the benefits of the watershed protection function on natural area at a local level was relatively straight forward (Table 1). As a consequence of the problem involved this non-use benefit of nature, works as illustrative example of environmental function wich are considered to be free. It is therefore essential to quantify the economic benefits of the non-use qualitative values on Table 1 through the use of shadow prices. For instance, the possibility of commercial fisheries on the nursery function of oxbow lakes on Mogi-Guaçu River wetlands, or the dependence of local agricultural productivity 
on natural biological control mechanisms provided by Ecological Station of Jataí should be reflected in price of the products. This added conservation value on fish and agricultural products should be used for the preservation and maintenance of the Ecological Station of Jataí.

Existence value it is related to the intangible, intrinsic and ethical values attributed to Ecological Station of Jataí. Part of the existence value deals with feelings of stewardship on behalf of non-human populations, reflecting the simpathy, responsibility and concern that some people feel toward wild species and natural ecosystems (Maroti \& Santos, 1998). The intrinsic value attributed to Ecological Station of Jataí and the wildlife her contain, is an important factor in the feeling of well-being to many people and is reflected in an ethical attitude towards nature. However, this ethical attitude is subject to both collective and individual environmental perception, wich differ depending on the cultural background (Santos et al., 1996). Although difficult to measure, both in descriptive and in economic terms (Table 1), the existence value is an important aspect of the socio-economic value people place on Ecological Station of Jataí (Obara, 1999) and should be included as such in the decision-making process. Often the existence value is the main justification for preserving natural areas, and dominates all other benefits of wildlife and natural ecosystems in the minds of some people (Pearsall, 1984).

The social value of Ecological Station of Jataí deals with the importance placed on maintaining the option to benefit from known and as of yet unknown functions of natural processes and components in the future (option value). Also yet like environmental functions contribute, directly or indirectly, to human health (value to human health), such as the regulation of the local climate, storage and recycling of human waste, pest control, medicinal resources etc. However, these values are indicated only in qualitative terms on Table 1. To ensure a option value for future benefits of Ecological Station of Jataí, the existing diversity of habitats and species should be maintained as much possible. The monetary estimate of option value for the Ecological Station of Jataí should be, at least, equal to the total value of the conservation and productive use values combined, wich amounts to more than US\$ 629.87/ha/year. To avoid double counting this value is not included.

Since the future is uncertain, all types of option value can be seen as means of assigning a value to risk aversion in the face of uncertainty (McNeely, 1988). New functions of natural ecosystems that have not yet been discovered can be categorized as a type of option value (serendipity value) (Pearsall, 1984).

The consumptive use value of environmental functions relates to the use of natural products wich are harvested directly from the Ecological Station of Jataí. However, in this natural area direct harvesting of natural products for subsistence reasons is rather limited and mainly relates to catching fish on oxbow lakes, reservoir and streams. Possibly some local inhabitant also collect firewood for personal use. It mainly deals with natural resources wich are included in the category of production functions and to some information functions, such as aesthetic quality and historic value of Ecological Station of Jataí (Table 1). Only some studies have been carried out on Ecological Station of Jataí to assess the importance of the direct use of wild plants to local community (Castelucci, 1995). Monetary quantification of these consumptive use values is rather difficult and has not been attempted within the scope of this case study.

The productive use value of environmental functions mainly relates to the use of natural resources, the use of the Ecological Station of Jataí as provider space for carrier (recreation) function and income from scientific expeditions (Table 1).

Another indicator for the socio-economic value of environmental function is their contribution to employment. The monetary value provided information and carrier functions, in terms of resources invested in development of research activities and nature protection allowed to estimate a total socio-economic value of US\$ 73.96/ha/year (Table 1).

The combined potential annual return of some functions provided by Ecological Station of Jataí is at least US\$ 708.83/ha/year (Table 1). In comparison to estimates accomplished for other natural ecosystems this is a rather moderate value. Gosselink et al. (1974) calculated a monetary value of US\$ 10,000.00/ha/year for several estuaries of the east coast of the USA; Thibodeau \& Ostro (1981) arrived at a value of US\$28,000.00/ha/year 
for the Charles River Basin, Massachusetts; Hair (1988) estimated a value of US\$ 3,600.00/ha/year of Atlantic Spartina Marsh; De Groot (1990) determined a value of US\$ 6,200.00/ha/year for three major ecosystems complexes on Dutch Wadden Sea and US\$120.00/ha the total monetary return from environmental functions in Galapagos (De Groot, 1988), and Grasso et al. (1995) estimated an average WTP value about US\$ 395.00/ ha/year to preserve mangrove located at Cananéia, SP (Table 2).

It must be realized that the total monetary value of Ecological Station of Jataí only represents the annual return from described functions on Table 1. Since utilised in a sustainable manner, Ecological Station of Jataí can be enjoyed indefinitely. The income derived from natural goods and services must therefore be seen as the interest of a capital-

TABLE 2

Annual return values from environmental (ecosystem services) functions (1) and natural capital (2) of different ecosystems.

\begin{tabular}{|l|c|c|l|}
\hline \multicolumn{1}{|c|}{ Ecosystems } & (1) US\$/ha/year & (2) US\$/ha & \multicolumn{1}{|c|}{ References } \\
\hline Estuaries of the east coast of the USA & 10,000 & 200,000 & Gosselink et al., 1974 \\
\hline Charles Riber Basin, Massachusetts, USA & 28,000 & 560,000 & Thibodeau \& Ostro, 1981 \\
\hline Atlantic Spartina sp. Marsh & 3,600 & 72,000 & Hair, 1988 \\
\hline Ecosystem complexes on Dutch Waden Sea & 6,200 & 124,000 & De Groot, 1990 \\
\hline Galapagos, Ecuador & 120 & 2,400 & De Groot, 1988 \\
\hline Ecological Station of Jataí, SP, Brazil & 708 & 14,160 & This study \\
\hline Cananéia, SP, Brazil & 395 & 7,900 & Grasso et al., 1995* \\
\hline
\end{tabular}

* Related only with average WTP value to preserve mangroves located at Cananéia, SP.

stock of natural processes and components wich provide these functions. The total annual value transformed into a capital value reflects the true economic value of the natural area in question. Instead of the use of discount rates (Hueting, 1991), a better approach to calculate the capital value of environmental functions would be the interest-on-capital approach (De Groot, 1992). At 5\% interest, a yearly return of US\$ 708.83/ha/year would represent a capitalized value of the functions of the Ecological Station of Jataí of about US\$14,160.00/ha (Table 2).

With the capital value is possible to compare the non-use value of this natural area with the monetary return calculated for a non-sustainable use.

Although the Ecological Station of Jataí, compared to other ecosystems, is poorly protected and managed, it too is still threatened by human activities accomplished in their surrounding area. To ensure the conservation of this natural area (and to stimulate the restoration of degraded areas), it is necessary to have a clear understanding of the many functions and socio-economic values of Ecological Station of Jataí in their natural state. Although the economic market doesn't recognise the monetary value of many environmental functions, such evaluation do provide a revealing insight into the great socio-economic importance of this natural area. And also more awareness of these values may provide an important incentive to their preservation and sustainable utilisation.

\section{REFERENCES}

ALBUQUERQUE, A. L. S. \& MOZETO, A. A., 1997, C : N : P Ratios and stable Carbon isotope compositions as indicators of organic matter sources in a riverine wetland system (Mogi-Guaçu River, São Paulo, Brazil). Wetlands, 17: 1-9.

BALLESTER, M. V. R., 1994, Dinâmica de gases biogênicos $\left(\mathrm{CH}_{4}, \mathrm{CO}_{2}\right.$ e $\left.\mathrm{O}_{2}\right)$ na planície de inundação do Rio MogiGuaçu (Estação Ecológica de Jataí, SP). Tese de Doutorado, UFSCar, São Carlos, 172p. 
BALLESTER, M. V. R., SANTOS, J. E. \& FERESIN, E. G., 1995, Desenvolvimento planejado (utilização do solo) da Estação Ecológica de Jataí. Oecologia Brasiliensis, I: 511 522 .

BARROSO, G. F., 1994, Sistema de avaliação de habitats aquáticos. Caso de estudo: Estação Ecológica de Jataí, Luiz Antônio, SP. Disseratação de Mestrado, UFScar, São Carlos, 131p.

CAMARGO, A. F. M. \& ESTEVES, F. A., 1995, Influence of water level variation on fertilization of an oxbow lake of Rio Mogi-Guaçu, State of São Paulo, Brazil. Hydrobiologia, 259: 185-193.

CARMO, F. M. S., 1994, Influência do teor de nitrogênio sobre aspectos da nodulação em Anadenanthera falcata (Benth) Mimosoideae. Dissertação de Mestrado, UNESP, Rio Claro, 103p.

CASTELUCCI, S., 1995, Um estudo etnobotânico sobre plantas medicinais levantadas junto aos moradores da Estação Ecológica de Jataí. DHB/UFSCar, São Carlos, $48 \mathrm{p}$.

CAVALHEIRO, F., BALLESTER, M. V. R., KRUSCHE, A. V., MELO, S. A., WAECHTER, J. L., DA SILVA, C. J., D'ARIENZO, M. C., SUZUKI, M., BOZELLI, R. L., JESUS, T. P. \& SANTOS, J. E., 1990, Propostas preliminares referentes ao plano de zoneamento e manejo da Estação Ecológica de Jataí, Luiz Antônio, SP. Acta Limnol. Brasil., 3: 951-968.

CETESB, 1991, Relatório de Qualidade das Águas Interiores do Estado de São Paulo, 164p.

COSTANZA, R., 1994, Economia Ecológica: Uma Agenda de Pesquisa. In: P. H. May \& R. S. Motta (orgs.), Valorando a Natureza: Análise Econômica para o Desenvolvimento Sustentado. Campus, Rio de Janeiro, pp. 111-144.

COSTANZA, R., d'ARGE, R., De GROOT, R., FARBER, S., GRASSO, M., HANNON, B., LIMBURG, K., NAEEM, S., O'EILL, R. V., PARUELO, J., RASKIN, R. G., SUTTON, P. \& van den BELT, M., 1997, The value of the world's ecosystem services and natural capital. Nature, 387(15): 253-260.

COUTINHO, M. E., 1989, Ecologia populacional de Eichhornia azurea (Kth) na dinâmica da vegetação aquática da Lagoa do Infernão, SP. Dissertação de Mestrado, UFSCar, São Carlos, 145p.

De GROOT, R. S., 1988, Functions and socio-economic importance of the natutal environment in the Galapagos Islands, Ecuador. Case study report. Nature Conservation Department. Agricultural University Wageningen. 99p.

De GROOT, R. S., 1990, Functions of the Dutch Wadden Sea. Workshop on "Wetlands are not Wastelands", Environment Canada, Ottawa, 27p.

De GROOT, R. S., 1992, Functions of Nature. WoltersNoordhoff, Amsterdan, 315p

De GROOT, R. S., 1995, Towards a conceptual framework for measuring ecological sustainability of ecosystems. Workshop on Sustainability of Ecosystems: Ecological and Economic Factors. Slovakia, Bratislawa, 33p.
DIAS JR., C., 1991, Ciclo anual do fitoplâncton e de algumas variáveis ambientais da Lagoa do Infernão, SP. Dissertação de Mestrado, UFSCar, São Carlos, 145p.

DIXON, J. A. \& SHERMAN, P. B., 1990, Economics of protected areas: a new look at benefits and costs. Island Press, Whasington, DC, 234p.

EHRLICH, P. R., 1985, The concept of Human Ecology: a personal view. IUCN Bulletin, 16: 60-61.

EHRLICH, P. R. \& MOONEY, H., 1983, Extinction, substitution and ecosystem services. Bioscience, 33(4): 248-253.

ESTEVES, K. E., 1992, Alimentação de cinco espécies forrageiras (Pisces, Characidae) em uma lagoa marginal do Rio Mogi-Guaçu, SP. Tese de Doutorado, UFSCar, São Carlos, 102p.

FREITAS, E. A. C., 1989, Bactérias do sedimento da Lagoa do Infernão (Luiz Antônio, SP). Distribuição temporal e composição por grupos produtores de exoenzimas. Dissertação de Mestrado, UFSCar, São Carlos, 89p.

GOSSELINK, J. G., ODUM, E. P. \& POPE, R. M., 1974, The value of the Tidal Marsh. Center for Wetland Resources. Louisiana State University, Baton Rouge, Louisiana, 30p.

GRASSO, M., TOGNELlA, M. M. P., SCHAEFFERNOVELLI, Y. \& COMUNE, A. E., 1995, Aplicação de técnicas de avaliação econômica ao ecossistema manguezal. In: P. H. May (org.), Economia Ecológica: Aplicações no Brasil. Ed. Campus, Rio de Janeiro, pp. 4981.

HAIR, J. D., 1988, The Economics of Conserving Wetlands: A Widening Circle. Workshop on Economics, IUCN General Assembly, Costa Rica, 140p.

HUETING, R., 1991, The use of the discount rate in a costbenefit analysis for different uses of a tropical forest area. Ecological Economics, 3: 43-57.

JESUS, T. P., 1993, Caracterização perceptiva da Estação Ecológica de Jataí (Luiz. Antônio, SP) por diferentes grupos sócio-culturais de interação. Tese de Doutorado, UFSCar, São Carlos, 378p.

LIMA, N. R. W., 1990, Análises dos níveis de metais pesados no sistema hídrico da Estação Ecológica de Jataí. Acta Limnol. Brasil., III: 1001-1021.

LORANDI, R., FREIRE, A., GONÇALVES, A. R. L. \& TRINDADE, M., 1990, Levantamento pedológico semidetalhado da bacia do córego do Jataí e suas aplicações. FINEP/CNPq/DCB, UFSCar, 79p.

MANTOVANI, J. E. Utilização do geoprocessamento e técnicas de rastreamento para mapeamento e preservação da população de lobo-guará na Estação Ecológica de Jataí, Luiz Antônio, SP. Tese de Doutorado, UFSCar, São Carlos (in prep.).

MARGARIDO, L. A. C., 1995, Valoração ambiental de alguns aspectos funcionais de uma área natural de conservação. Estudo de caso: Estação Ecológica de Jataí, Luiz Antônio, $S P$. Tese de Doutorado, UFSCar, São Carlos, 92p.

MARGARIDO, L. A. C. \& CASTILHO, H. J., 1988, 
Determinação do nível de dano econômico da broca de cana-de-açúcar (Diatraea saccharalis F.) para destilarias de álcool. Brasil Açucareiro, 10(4): 41-46.

MARGARIDO, L. A. C. \& SANTOS, J. E., 1996, Controle da erosão: um serviço executado pela natureza. Anais VII Sem. Reg. Ecologia, VII: 303-308.

MAROTI, P. S. \& SANTOS, J. E., 1998, Caracterização perceptiva de uma área natural de conservação por docentes do ensino fundamental. Rev. Univille, 3(2): 5566.

McNEELY, J. A., 1988, Economics and Biological Diversity: developing and using economic incentives to conserve biological resources. IUCN, Gland, Switzerland, 232p.

MESCHIATTI, A. J., 1998, Ecologia de peixes associados às macrófitas em duas lagoas marginais do Rio MogiGuaçu. Tese de Doutorado, UFSCar, São Carlos, 121p.

NOGUEIRA, F., 1995, O método de análise funcional do ecossistema. Caso de estudo: bacia do Rio Bento Gomes (Pantanal de Poconé, MT), com ênfase nas funções ambientais afetadas pela mineração de ouro. Tese de Doutorado, UFSCar, São Carlos, 222p.

NOGUEIRA, F., ESTEVES, F. \& PRAST, A. E., 1996, Nitrogen and phosphorus concentration of different structures of the aquatic macrophytes Eichhornia azurea Kunth and Scirpus cubensis Poep \& Kunth in relation to water level variation in Lagoa do Infernão (São Paulo, Brazil). Hydrobiologia, 328: 199-205.

OBARA, A. T., 1992, Dinâmica da fixação do nitrogênio e a influência de herbicidas na comunidade de diazotróficos perifíticos das raizes de Scirpus cubensis (Lagoa do Infernão, Estação Ecológica de Jataí, Luiz Antônio, SP). Dissertação de Mestrado, UFSCar, São Carlos, 155p.

OBARA, A. T., 1999, Valoração econômica de unidades de conservação. Método de valoração contingente. Caso de estudo: Estação Ecológica de Jataí (Luiz Antônio, SP). Tese de Doutorado, UFSCar, São Carlos, 110p.

OBARA, A. T., SANTOS, J. E., BENZE, B. G. \& SCHUNKSILVA, E., 1999, Valoração econômica de unidades de conservação: caso de estudo Estação Ecológica de Jataí (Luiz Antônio, SP). Cad. Biodivers., 2(1): 82-94.

PEARCE, D. \& TURNER, R. K., 1990, Economics of natural resources and the environment. Harvester Wheatsheaf, New York \& London, 378p.

PEARSALL, S., 1984, In Absentia Benefits of Natural Reserves: A Review. Environmental Conservation, 11(1): 310.

PINTO, M. T. C., 1992, Dinâmica de nutrientes na mata galeria da Lagoa do Diogo (Estação Ecológica de Jataí, Luiz Antônio, SP). Tese de Doutorado, UFScar, São Carlos, 366p.

PIRES, A. M. Z. C. R., 1994, Elaboração de um banco de dados digitais georreferenciados como subsídio ao pla- nejamento e manejo de uma unidade de conservação - Estação Ecológica de Jataí (Luiz Antônio, SP). Dissertação de Mestrado, UFSCar, São Carlos, 68p.

PIRES, A. M. Z. C. R., 1999, Diretrizes sobre a Conservação da Biodiversidade em planos de manejo de unidades de conservação. Caso de Estudo: Estação Ecológica de Jataí e Estação Experimental de Luiz Antônio (Luiz Antônio, SP). Tese de Doutorado, UFSCar, São Carlos, 210p.

PIRES, A. M. Z. C. R., SANTOS, J. E. \& PIRES, J. S. R., 1998a, Elaboração de um banco de dados georreferenciados para caracterização ambiental de uma unidade de conservação. Anais VII Sem. Reg. Ecologia, II: 585-598.

PIRES, J. S. R., 1995, Análise Ambiental voltada ao Planejamento e Gerenciamento do Ambiente rural. Abordagem Metodológica Aplicada ao município de Luiz Antônio, SP. Tese de Doutorado, UFSCar, São Carlos, $194 \mathrm{p}$.

PIRES, J. S. R. \& SANTOS, J. E., 1996, Preliminary analysis of environmental impacts applied to a rural area of São Paulo State (Luiz Antônio, SP, Brazil). International Association for Impact Assessment, II: 969-974.

PIRES, J. S. R., SANTOS, J. E., PIRES, A. M. Z. C. \& HENKE-OLIVEIRA, C., 1998b, Abordagem metodológica para identificação de fragmentos de áreas naturais. VIII Sem. Reg. Ecologia, II: 571-584.

RISSER, P. G., 1985, Toward a holistic management perspective. BioScience, 35: 414-418.

SANTOS, J. E., BALlESTER, M. V. R., JESUS, T. P., PIRES, J. S. R. \& OBARA, A. T., 1995, Abordagem sistêmica para o manejo de áreas naturais de conservação. Caso de estudo: Estação Ecológica de Jataí, Luiz Antônio, SP. Oecologia Brasiliensis, I: 487-502.

SANTOS, J. E., JESUS, T. P., HENKE-OLIVEIRA, C. \& BALLESTER, M. V. R., 1996, Caracterização perceptiva da Estação Ecológica de Jataí (Luiz Antônio, SP) por diferentes grupos sócio-culturais de interação. Anais VII Sem. Reg. Ecologia, VII: 309-353.

SÃO PAULO (Estado), 1985, Áreas Naturais do Estado de São Paulo. Conselho Estadual do Meio Ambiente, 168p.

SCHWARZBOLD, A., 1992, Efeitos do regime de inundação do Rio Mogi-Guaçu (SP) sobre a estrutura, diversidade, produção e estoques do perifíton da Lagoa do Infernão. Tese de Doutorado, UFSCar, São Carlos, 237p.

SILVA, A. M. K., 1997, Percepção ambiental do grupo tomador de decisão do município de Luiz Antônio, SP. Estudo de caso. Dissertação de Mestrado, UFSCar, São Carlos, $120 \mathrm{p}$.

SIMÕES FILHO, F. F. L., 1993, A hidrodinâmica de particulado em planícies de inundação: um estudo sobre as taxas de sedimentação de lagoas marginais do Rio Mogi-Guaçu, Estação Ecológica de Jataí (Luiz Antônio, $S P)$. Dissertação de Mestrado, UFSCar, São Carlos, 105p. 
TALAMONI, S. A., 1996, Ecologia de uma comunidade de pequenos mamíferos da Estação Ecológica de Jataí, município de Luiz Antônio, SP. Tese de Doutorado, UFSCar, São Carlos, 177p.

TALAMONI, S. A. \& MOTTA JR., J. C., 1994, Presas consumidas pelo lobo-guará (Chrysocyon brachyurus, Mamalia, Canidae) na Estação Ecológica de Jataí, Município de Luiz Antônio. Congresso Brasileiro de Zoologia, Rio de Janeiro, 20p.

TALAMONI, S. A., MOTTA JR., J. C. \& DIAS FILHO, M. M., 1994, Mamíferos não voadores das Estações Ecológica e Experimental de Jataí, Luiz Antônio, SP.
Estudos Preliminares. Workshop Projeto Jataí, São Carlos.

THIBODEAU, F. R. \& OSTRO, B. D., 1981, An Economic Analysis of wetland protection. J. of Environ. Management, 12: 19-30.

TOLEDO FILHO, D. V., 1984, Composição florística e estrutura fitossociológica da vegetação de cerrado do município de Luiz Antonio (SP). Dissertação de Mestrado, Instituto de Biociências, UNICAMP, Campinas, $173 \mathrm{p}$.

WESTMAN, W. E., 1977, How much are nature's service worth? Science, 197: 960-963. 